\title{
ANALISIS WACANA KRITIS PEMBERITAAN PENATAAN TAMAN NASIONAL KOMODO PADA TRIBUNNEWS.COM DAN DETIK.COM
}

\author{
Muhammad Guruh Achmad Teguh ${ }^{1 *}$, Rini Riyantini², dan Intan Putri Cahyani ${ }^{3}$ \\ ${ }^{1,2,3}$ Universitas Pembangunan Nasional Veteran Jakarta, Jakarta Selatan, Indonesia. \\ *muhammadgat@upnvj.ac.id
}

\begin{abstract}
The arrangement of the Komodo National Park which will turn this national park into a premium tourist destination has caused controversy between the people who disagree with the arrangement and the government. The existing arrangement is feared to disturb the habitat and the original ecosystem of the Komodo dragon and will complicate conservation activities. This controversy has increasingly attracted public attention with the appearance of photos of Komodo blocking trucks that go viral on social media. The mass media in this case also reported on this. This research was conducted to prove the alignment of the news on the arrangement of the Komodo National Park on tribunnews.com and detik.com. Which is carried out using the critical discourse analysis method on news texts in both media. This study uses a qualitative approach so that it can see more deeply the meaning behind the discourse. The research proves that the media tend to choose one party in constructing an event. Tribunnews.com proved to be in favor of the government by displaying statements submitted by the government and positive things from the arrangement. On the other hand, detik.com shows siding with the people who voice their rejection and view the existing arrangement negatively.
\end{abstract}

Keywords: Discourse Analysis; Detik.com; News; The arrangement of Komodo National Park; Tribunnews.com.

\begin{abstract}
Abstrak
Penataan Taman Nasional Komodo yang akan mentransformasi taman nasional ini menjadi destinasi pariwisata premium menimbulkan kontroversi antara masyarakat yang menolak penataan dengan pemerintah. Penataan yang ada dikhawatirkan akan mengganggu habitat dan ekosistem asli dari satwa Komodo serta akan menyulitkan kegiatan konservasi. Kontroversi ini semakin menarik perhatian masyarakat dengan kemunculan foto seekor Komodo menghadang truk yang viral di sosial media. Media massa dalam hal ini, turut serta melakukan pemberitaan mengenai peristiwa tersebut. Penelitian ini dilakukan untuk membuktikan keberpihakan pemberitaan penataan Taman Nasional Komodo pada tribunnews.com dan detik.com. yang dilakukan menggunakan metode analisis wacana kritis pada teks berita di kedua media. Penelitian ini menggunakan pendekatan kualitatif sehingga dapat melihat lebih dalam makna dibalik wacana. Dari penelitian membuktikan bahwa media cenderung memilih satu pihak dalam mengonstruksi satu peristiwa. Tribunnews.com terbukti memihak pemerintah dengan menampilkan pernyataan yang disampaikan oleh pemerintah dan hal-hal positif dari adanya penataan. Di sisi lain, detik.com menunjukkan keberpihakan pada masyarakat yang menyuarakan penolakan dan memandang negatif atas penataan yang ada..
\end{abstract}

Kata Kunci: Wacana kritis; Detik.com; Pemberitaan, Penataan Taman Nasional Komodo; Tribunnews.com.

\section{PENDAHULUAN}

Taman Nasional Komodo, terletak di tengah Kepulauan Indonesia, di antara Pulau Sumbawa dan Pulau Flores. Taman Nasional ini terdiri atas tiga pulau utama yaitu P. Rinca, P. Komodo, dan P. Padar disertai dengan banyak pulau kecil lainnya. Taman Nasional Komodo telah ditetapkan sebagai kawasan 
prioritas konservasi global. Komodo menjadi hewan yang menjadi daya tarik TN ini karena hanya dapat ditemui di TN ini (Unesco.org). Seperti yang diatur dalam Peraturan Pemerintah RI Nomor 28 Tahun 2011 tentang Pengelolaan Kawasan Suaka Alam dan Kawasan Pelestarian Alam pasal 1 nomor 9 "Taman Nasional adalah Kawasan Pelestarian Alam (KPA) yang mempunyai ekosistem asli, dikelola dengan sistem zonasi yang dimanfaatkan untuk tujuan penelitian, ilmu pengetahuan, pendidikan, menunjang budidaya, pariwisata, dan rekreasi". Taman Nasional Komodo ditetapkan sebagai Taman Nasional lewat keputusan Menteri Kehutanan nomor 306/KPTS-II/1992 pada tanggal 29 Februari tahun 1992.

Penataan TN Komodo yang sedang berlangsung akan mentransformasi Taman Nasional ini menjadi destinasi wisata premium dengan pendekatan konsep geopark yang mengedepankan perlindungan serta penggunaan warisan geologi dengan cara yang berkelanjutan. Pembangunan di kawasan Taman Nasional Komodo telah dicanangkan sejak tahun 2018, dan menjadi perbincangan hangat dalam masyarakat. Pro dan kontra terkait dengan penataan Taman Nasional ini banyak bermunculan, hal ini berujung kepada munculnya tagar save komodo (\#savekomodo) yang diserukan oleh para aktivis pecinta lingkungan, artis, hingga masyarakat lokal yang berujung kepada penghentian pembangunan sementara.

Peraturan mengenai pembangunan di TN Komodo tertuang dalam Peraturan Menteri Kehutanan Republik Indonesia nomor P.4/Menhut-II/2012 pasal 26 yang mengatur bahwa area yang diizinkan untuk dilakukan pembangunan sebagai sarana wisata alam maksimal seluas $10 \%$ dari luas area yang ditetapkan dalam izin dan merupakan penjumlahan luas tapak pondasi bangunan untuk sarana wisata alam tersebut. Sarana wisata alam dalam pasal 8 ayat 1 yaitu wisata tirta, akomodasi, transportasi, dan wisata pembangunan. Dan dalam ayat 2 dijelaskan pula pembangunan dapat dilakukan di zona pemanfaatan yang merupakan bagian dari $\mathrm{TN}$ yang dijadikan tempat pariwisata alam dan juga kunjungan wisata. Bentuk dari bangunan sarana wisata alam yang diizinkan adalah bangunan semi permanen yang bentuknya disesuaikan dengan arsitektur budaya setempat.

Proses penataan TN Komodo dalam prosesnya akan mengganggu konservasi serta kehidupan warga lokal. Perubahan zonasi yang dilakukan berkali-kali oleh KLHK menjadikan zona konservasi semakin sempit yang merupakan efek dari perluasan zona pemanfaatan., Penduduk dalam kawasan ini terutama yang berada di Desa Komodo akan terancam direlokasi dan/atau dibatasi aktivitas kegiatan ekonominya. Kemunculan bangunan pada kawasan ini akan mengganggu keindahan panorama alam dan akan mengganggu konservasi, berbagai jenis limbah juga akan muncul juga akan mengganggu ekosistem komodo (Sunspirit for Justice and Peace, 2020).

Pada Januari 2019 gubernur NTT mewacanakan penataan TN Komodo dengan tujuan untuk konservasi dan wisata dan hal ini disepakati oleh presiden Joko Widodo dan Pulau Komodo pun direncanakan akan ditutup sementara dari aktivitas wisata dan akan dijadikan wilayah konservasi (Mongabay.co.id). Namun, dalam prosesnya tak jarang muncul konflik antara penduduk lokal dengan pihak manajemen dari Taman Nasional. Bahkan ditemukan juga sejumlah kasus pembunuhan terhadap 2 nelayan lokal pada tahun 2002 ketika sedang menangkap ikan di kawasan perbatasan TN Komodo. Tak hanya itu beberapa tindak kekerasan, ancaman, dan penyiksaan juga diterima para nelayan lokal (Borchers, 2005).

Dalam penelitian Asriyani dan Verheijen (2020) mengungkap fakta bahwa dalam perkembangan penataan TN Komodo sering kali dilakukan pengambilan keputusan satu pihak oleh pihak TN Komodo tanpa adanya persetujuan dari penduduk lokal. Berbagai lokasi yang biasa mereka gunakan untuk pelaksanaan kegiatan adat secara sepihak telah masuk ke dalam kawasan konservasi. Pihak Balai Konservasi Sumber Daya Alam (BKSDA) tidak melakukan diskusi dengan 
penduduk lokal dan penduduk lokal pun tidak mengetahui wewenang dari BKSDA dalam penyusunan aturan konservasi (Asriyani \& Verheijen, 2020). Penutupan TN Komodo pada tahun 2018 ditetapkan tanpa persetujuan dari warga lokal, dan berbagai macam perencanaan mendatang akan dilakukan secara cepat tanpa memikirkan kepentingan penduduk lokal. Ide untuk menjadikan TN Komodo menjadi destinasi wisata premium adalah gambaran yang salah dari Komodo yang sebenarnya dan akan menghilangkan fakta sejarah bahwa masyarakat lokal pernah hidup berdampingan dengan Komodo (Lasso \& Dahles, 2018).

Perkembangan pariwisata pada $\mathrm{TN}$ Komodo menjadi salah satu upaya pemerintah untuk meningkatkan pertumbuhan ekonomi, terutama ekonomi pada daerah pedesaan (Ardiani \& Ardhyanto, 2017). Akan tetapi Kurniawan (2019) dalam penelitiannya menunjukkan bahwa kegiatan pariwisata dengan panorama alam yang alami menjadi salah satu faktor utama yang menjadi motivasi wisatawan untuk berkunjung ke TN Komodo dan memberikan dampak positif bagi wisatawan seperti pelajaran, peningkatan suasana hati, dan dalam jangka waktu Panjang akan menumbuhkan kesadaran untuk mencintai lingkungan. Selain itu, Lasso dan Dahles (2018) menyatakan bahwa pembangunan pariwisata menjadikan masyarakat yang mayoritas bermata pencaharian sebagai nelayan menjadi penjual cendera mata. Walaupun pekerjaan ini mencukupi kebutuhan masyarakat lokal, potensi ancaman pekerjaan ini seperti pasar yang terbatas, persaingan yang ketat, periode wisatawan yang singkat, serta ketergantungan yang tinggi pada kunjungan kapal pesiar, masih belum menjanjikan. Pembangunan yang ada tentu juga akan menyulitkan perlindungan pada kawasan alam yang luas yang diakibatkan dari adanya perkembangan ekonomi dan aktivitas manusia pada area ini (Sitorus, 2011).

Pada Oktober 2020 penataan kembali dilakukan. Penataan ulang yang sedang berlangsung di Taman Nasional Komodo merupakan proyek garapan Kementerian Pekerjaan Umum dan Perumahan Rakyat
(PUPR) berlokasi di Lembah Loh, Pulau Rinca, Taman Nasional Komodo. Penataan ini menarik banyak perhatian masyarakat bersamaan dengan munculnya sebuah potret seekor komodo yang menghadang sebuah truk dengan muatan material bahan bangunan. Munculnya banyak potret tersebut menjadikan \#savekomodo viral kembali setelah sebelumnya sempat viral di tahun 2018 pada Senin, 26 Oktober 2020. Viralnya tagar ini memicu banyak masyarakat memberikan komentar mengenai pendapat mereka terkait dengan penataan TN Komodo yang berujung kepada munculnya kembali petisi online yang menolak pembangunan pada kawasan ini yang pertama kali muncul pada tahun 2018 lalu melalui platform petisi online Change.org.

Dalam proses penataannya, berita terkait dengan penataan Taman Nasional Komodo banyak bermunculan di berbagai media massa, termasuk pada media berita online. Media massa merupakan infrastruktur kekuasaan (power) namun di sisi lain juga menjadi kontrol sosial. Hal ini kemudian menyebabkan munculnya benturan kepentingan (Santoso, 2016). Masing-masing media online melakukan pemberitaan mengenai penataan Taman Nasional ini dengan judul dan juga isi yang bervariasi. Variasi dari perbedaan pemberitaan menurut Arsam (2014) berkaitan dengan kepemilikan media massa yang dapat mempengaruhi bagaimana sebuah wacana, yang dalam hal ini berupa berita, dipublikasikan. Menurut pandangan kritis, realitas yang ada tidaklah ada yang benar-benar riil, hal ini dikarenakan realitas muncul dan terbentuk melalui proses sejarah dan kekuatan sosial, politik, dan ekonomi (Eriyanto, 2017). Proses ini yang kemudian menjadikan setiap wacana yang muncul mengandung nilai-nilai, ideologi, dan kepentingan dari media yang mempublikasikan wacana tersebut (Humaira, 2018).

Media online Tribunnews.com dan Detik.com merupakan dua media yang ikut menyajikan berita terkait dengan penataan taman nasional Komodo. Kedua media ini menempati posisi pertama dan kedua sebagai 
website dalam kategori media dan berita di Indonesia (Similarweb.com, 2020). Tribunnews.com berdiri pada tahun 2010 dikelola oleh PT. Tribun Digital Online merupakan divisi dari Koran Daerah Kompas Gramedia yang didirikan oleh Jakob Oetama dan P.K. Ojong (tribunnews.com). Dalam melakukan pemberitaan terkait penataan $\mathrm{TN}$ Komodo tribunnews.com melakukan pemberitaan dengan sudut pandang pemerintah. Terlebih Tribunnews.com memandang positif kinerja dari pemerintahan Jokowi (Kusuma Wardani, 2017).

Detik.com berdiri sejak tanggal 9 Juli 1998 yang didirikan oleh Budiono Darsono, Yayan Sopyan, Abdul Rahman, dan Didi Nugrahadi sebelum kemudian diakuisisi oleh CT Corp pada tanggal 3 Agustus 2011. Saat ini Detik.com merupakan bagian dari CT Corp yang dimiliki oleh Chairil Tanjung. Detik.com menganut sistem komunikasi Pancasila berbasis ideologi Pancasila (Al kafi, 2020). Hal ini juga dapat dilihat dari pemberitaan yang dipublikasikan terkait dengan penataan TNK yaitu banyak berita yang mengonstruksi peristiwa dari sudut pandang penduduk lokal.

Perbedaan penyajian berita seperti penggunaan aspek kebahasaan yang berbeda, menjadikan hal ini menarik untuk diteliti. Dari penelitian yang dilakukan oleh Alfaritsi, et al. (2020) menunjukkan hasil bahwa media dalam melakukan pemberitaan akan cenderung mendukung satu pihak. Edy Prihantoro (2013) dalam penelitiannya juga menunjukkan hasil bahwa wacana yang ada pada suatu media dibentuk sesuai dengan idealisme dari masingmasing media. Berangkat dari penelitian terdahulu peneliti melihat bagaimana keberpihakan media tribunnews.com dan detik.com dalam melakukan pemberitaan terkait dengan penataan TN Komodo.

Penelitian ini menggunakan analisis wacana kritis (Critical Discourse Analysis) yang fokus kepada bagaimana penyalahgunaan kekuasaan ataupun dominasi ketidakadilan direproduksi melalui konteks sosial politik. Wacana dalam analisis ini tidak hanya dipandang sebagai sebuah studi bahasa.
Penggunaan bahasa dalam analisis wacana kritis tidak hanya dianalisis sebagai gambaran dari aspek kebahasaan, tetapi juga menghubungkan dengan konteks yang berarti bahasa digunakan sebagai tujuan dan praktik tertentu dan praktik kekuasaan termasuk di dalamnya (Eriyanto, 2017).

Wacana ditinjau dari sudut sebuah komposisi atau karangan yang utuh dilihat dari bagaimana landasan utama dari masing-masing karangan memiliki tujuan yang berbeda satu sama lain yang merupakan tujuan umum sebuah karangan yang ingin dicapai. Keraf dalam Sobur (2018) menjelaskan bahwa terdapat empat kebutuhan dasar manusia yang dapat terpenuhi dalam sebuah karangan, yang dapat berwujud: (1.) Keinginan untuk memberikan informasi kepada orang lain dan menerima informasi kepada orang lain mengenai hal tertentu, (2.) Keinginan untuk meyakinkan seseorang terkait dengan suatu fakta dan mempengaruhi sikap dan perilaku orang tersebut, (3.) Keinginan untuk menceritakan bagaimana bentuk atau wujud dari suatu barang atau objek, atau menjelaskan deskripsi dari cita rasa suatu benda, hal, ataupun bunyi, dan (4.) Keinginan untuk bercerita kepada orang lain mengenai kejadian ataupun peristiwa yang terjadi, baik itu dialami diri sendiri ataupun yang didengar melalui orang lain.

Adapun karakteristik dari analisis wacana kritis dari Teun A. van Dijk, Fairclough, Wodak dalam Eriyanto (2017) adalah sebagai berikut: (1.) Tindakan, wacana dalam hal ini diasosiasikan sebagai bentuk dari interaksi. Maka dari itu wacana dipandang sebagai sesuatu yang memiliki tujuan baik itu mempengaruhi, mendebat, membujuk, menyangga, bereaksi dan sebagainya. Kemudian wacana juga dipahami sebagai sesuatu yang diekspresikan dengan sadar dan terkontrol, (2.) Konteks, dalam analisis wacana kritis konteks dari wacana seperti latar, situasi, peristiwa, dan kondisi dijadikan sebuah pertimbangan. Wacana dipandang diproduksi, dimengerti, dan dianalisis pada suatu konteks tertentu. Konteks yang mempengaruhi produksi wacana pertama, partisipan, latar siapa yang 
memproduksi suatu teks. Kedua, setting sosial tertentu, seperti tempat, waktu, posisi, pembicara dan pendengar atau lingkungan fisik, (3) Historis, dengan melakukan penempatan wacana dalam konteks sosial tertentu, hal ini berarti sebuah wacana diproduksi dalam konteks tertentu dan tidak dapat dimengerti tanpa ada konteks yang menyertainya dan menempatkan wacana ke dalam konteks historis tertentu menjadi salah satu aspek penting untuk dapat memahami teks, (4.) Kekuasaan, wacana dalam hal ini dipandang sebagai bentuk dari pertarungan kekuasaan. Dengan analisis wacana kritis wacana juga dihubungkan dengan kekuatan dan kondisi sosial, politik ekonomi, serta budaya tertentu. Dengan menghubungkan wacana dengan kekuasaan dapat dilihat apa yang disebut sebagai kontrol. Tak hanya kontrol dalam bentuk fisik dan langsung tapi juga kepada kontrol secara mental ataupun secara psikis, dan (5.) Ideologi,

teks, percakapan, dan lainnya merupakan bentuk dari sebuah praktik ideologi yang mencerminkan ideologi tertentu. Wacana merupakan pencerminan dari ideologi tertentu. Sehingga dalam suatu wacana akan selalu terkandung ideologi untuk mendominasi dan mempengaruhi.

Banyaknya pemberitaan di berbagai media online turut serta membangun opini masyarakat terkait dengan penataan TN tersebut. Masing-masing media melakukan konstruksi peristiwa sesuai dengan ideologi media masing-masing. Dengan menggunakan analisis wacana kritis suatu wacana dapat dianalisis sebagai bentuk dari sebuah praktik sosial. Efek ideologi juga sering kali dalam praktik sosial dalam bentuk wacana. Hal ini memunculkan pertanyaan penelitian yaitu bagaimana keberpihakan media tribunnews.com dan detik.com dalam pemberitaan penataan Taman Nasional Komodo? Yang bertujuan untuk membuktikan keberpihakan pemberitaan penataan Taman Nasional Komodo pada tribunnews.com dan detik.com.

\section{METODOLOGI PENELITIAN}

Penelitian ini menggunakan paradigma kritis yang akan melihat makna yang ada pada suatu wacana sampai kepada proses produksi dan reproduksi makna yang terjadi, baik secara historis ataupun institusional. Dengan menggunakan pendekatan kualitatif peneliti akan melihat lebih dalam makna dibalik wacana yang dipublikasikan oleh Tribunnews.com dan Detik.com terkait dengan pemberitaan penataan Taman Nasional Komodo sehingga dapat melihat keberpihakan media dalam melakukan pemberitaan terkait dengan peristiwa tersebut.

Jenis penelitian ini adalah wacana media yang dilakukan dengan mengumpulkan dan menganalisis wacana yang terdapat pada portal berita online Tribunnews.com dan Detik.com terkait dengan penataan Taman Nasional Komodo sehingga dapat memberikan gambaran terkait dengan keberpihakan media dalam mengonstruksi peristiwa.

Metode analisis data akan dilakukan dengan menggunakan analsis wacana kritis model van Dijk. Dengan menggunakan analisis wacana kritis, suatu wacana tidak hanya dianalisis untuk mengetahui isi teks berita, akan tetapi analisis juga dilakukan untuk melihat bagaimana pesan itu disampaikan. Sehingga dengan melihat bagaimana struktur kebahasaan dari suatu wacana dibangun, analisis wacana mampu melihat makna tersembunyi dari suatu teks (Eriyanto, 2017).

Dalam dimensi teks, yang diteliti adalah Struktur dari teks. Van Dijk memanfaatkan dan mengambil analisis linguistik untuk memberikan penjelasan dan memaknai suatu teks. Kognisi sosial adalah dimensi yang menjelaskan bagaimana suatu teks diproduksi oleh individu/kelompok pembuat teks. Analisis sosial melihat bagaimana teks kemudian dihubungkan lebih jauh dengan struktur sosial dan pengetahuan yang berkembang dalam masyarakat atas suatu wacana.

Analisis akan dilakukan pada 5 berita dari masing-masing media yang muncul pada 26 Oktober 2020 hingga tanggal 28 Oktober 2020 dengan kriteria yaitu memiliki tema berita yang sama. Kriteria ini penulis pilih karena, 
dalam pandangan analisis wacana kritis realitas yang muncul pada media terbentuk melalui proses sosial dan politik. Dengan demikian, walaupun tribunnews.com dan detik.com melakukan pemberitaan dengan tema berita yang sama, akan muncul perbedaan dalam bagaimana masing-masing media mengonstruksi tema tersebut. Periode tersebut yang menjadi perbincangan hangat masyarakat hingga munculnya kembali petisi online untuk menolak pembangunan di TN Komodo dan petisi lain yang menginginkan pencabutan izin pembangunan di TN Komodo.

\section{HASIL DAN PEMBAHASAN}

Hasil penelitian dari penelitian ini disajikan berdasarkan elemen analisis wacana kritis model van Dijk yang terdiri atas: (1.) Analisis teks, dilakukan terhadap teks berita yang telah ditentukan sebagai sampel penelitian berjumlah masing-masing 5 dari Tribunnews.com dan Detik.com, (2.) Kognisi sosial, dilakukan dengan melihat ideologi dari media dan menghubungkan ideologi tersebut dengan teks yang muncul dari masing-masing media, dan (3.) Analisis sosial, dilakukan dengan menelusuri bagaimana wacana diproduksi dan dimaknai oleh masyarakat.

Adapun judul dari berita yang menjadi subjek penelitian yaitu pada Tribunnews.com, (1) Trending \#SaveKomodo di Twitter, Warganet Khawatir Habitat Pulau Komodo Rusak, Ini Kata Pemerintah, (2) Viral Foto Komodo Berhadapan dengan Truk di Pulau Rinca, Bintang Emon : Ambil Aja Bos Semuanya, (3) Foto Komodo Hadang Truk Viral di Media Sosial, BTNK Keluarkan Surat Edaran Penutupan Pulau Rinca, (4) Menyoal Proyek Jurassic Park, Pemerintah NTT: Nilai Ekonomi Masyarakat Daerah Naik, dan (5) KLHK: Penataan Sarana dan Prasarana di Pulau Rinca Dibuat Terpusat.

Pada Detik.com (1) Komodo Vs Truk, \#SaveKomodo Bergema di Medsos, (2) Travel Influencer Soroti Pembangunan Jurassic Park Komodo, (3) Penutupan Pulau Rinca Dinilai Batasi Publik untuk Awasi Pembangunan, (4) Pulau Rinca Ditutup, Pelaku Wisata Menjerit, dan (5) Jeritan Hati Pulau Rinca yang Belum Kamu Dengar.

\section{Analisis Teks}

Dalam konteks tekstual pemberitaan penataan taman nasional Komodo pada tribunnews.com menunjukkan keberpihakan pada pemerintah dan terlihat mendukung adanya penataan pada kawasan ini. Hal ini terlihat dari bagaimana teks disusun oleh penulis dan selalu menampilkan fakta serta dampak baik dari adanya penataan yang ada. Selain itu pemilihan kutipan hanya menggunakan pernyataan yang disampaikan oleh pemerintah. Berbeda dengan Tribunnews.com, Detik.com di sisi lain secara tekstual mempublikasikan berita yang menunjukkan keberpihakan kepada masyarakat yang menolak pembangunan di kawasan taman nasional Komodo. Hal ini terlihat dari bagaimana penulis memberikan keterangan dari Masyarakat Peduli dan Penyelamat Pariwisata yang menyampaikan keadaan terkini di P. Rinca.

\section{Kognisi Sosial}

Kognisi sosial dari wartawan memberikan pengaruh kepada teks berita yang diproduksi dan hal ini dipengaruhi oleh ideologi media. Pada tribunnews.com yang secara tekstual menunjukkan keberpihakan pada pemerintah yaitu mendukung adanya penataan di kawasan taman nasional Komodo merupakan pengaruh dari ideologi media ini. Menurut penelitian yang dilakukan oleh Cahya Ningrum (2017) menunjukkan hasil bahwa media ini memberikan pandangan positif dari kinerja dua tahun pemerintahan Jokowi-JK. Tribunnews.com merupakan Divisi Koran Daerah Kompas Gramedia (Group of Regional Newspaper) yang didirikan oleh Jakob Oetama dan P. K. Ojong.

Tribunnews.com berdiri atas inisiatif dari pendirinya untuk melawan kegiatan pers komunis. Kompas Gramedia yang tadinya tampil sebagai sebuah media melawan komunisme bergeser menjadi media yang berorientasi profit. Hal ini dapat dilihat dari 
penyebaran produk kompas Gramedia yang semakin kuat dan mulai melahirkan beberapa anak perusahaan atau bisnis yang variatif mulai dari media cetak, percetakan, penerbitan buku, radio, stasiun televisi, hingga universitas. Sehingga hal ini yang menjadikan tribunnews.com muncul sebagai sebuah media yang tidak memiliki banyak larangan dalam melakukan penulisan berita dan lebih mementingkan bagaimana berita menarik minat pembaca (Bogia, 2016). Hal ini juga kemudian dapat menjelaskan bagaimana kemudian berita tribunnews.com muncul dengan judul berita clickbait dan dalam memberitakan peristiwa penataan taman nasional Komodo berpihak pada pemerintah dikarenakan hanya mementingkan ketertarikan pembaca dibandingkan dengan isi berita.

Di sisi lain, detik.com yang menunjukkan keberpihakan pada masyarakat yang menolak penataan di taman nasional Komodo secara tekstual dipengaruhi oleh ideologi media ini yang komunikasi Pancasila berbasis ideologi Pancasila. Nilai-nilai nasionalisme juga selalu diterapkan pemilik media Chairil Tanjung dalam tiap pemberitaannya (Al Kafi, 2020). Chairil tanjung sempat menjadi menteri koordinator bidang perekonomian Indonesia (19 Mei 2014 - 20 Oktober 2014), Menteri Kehutanan Indonesia (1 Oktober 2014 - 20 Oktober 2014), Menteri Energi dan Sumber Daya Mineral (11 September 2014 - 20 Oktober 2014) pada masa pemerintahan Susilo Bambang Yudhoyono.

Walaupun pernah menjadi bagian dari pejabat pemerintahan Indonesia, Chairil tanjung tidak menjadi salah satu pendukung dari pemerintahan Jokowi. Dilansir dari Tempo.co (2018) Jokowi hanya didukung oleh tiga pemilik media massa yaitu Surya Paloh yang merupakan pemilik dari harian Media Indonesia, Lampung Post, tabloid Prioritas, Metro TV, Medcom.id, MediaIndonesia.com, MetroTVNews.com, dan Lampost.co, Hary Tanoesoedibjo pemilik dari MNC Group, dan Erick Thohir yang merupakan pemilik dari Maha Group. Hal ini juga menjadi salah satu alasan mengapa kemudian Detik.com tidak menunjukkan dukungannya terhadap adanya penataan di kawasan TN Komodo.

\section{Analisis Sosial}

Taman nasional Komodo merupakan salah satu taman nasional yang ada di Indonesia dengan satwa Komodo sebagai satwa andalan dari taman nasional ini. Hal ini dikarenakan satwa Komodo hanya dapat hidup dan ditemui di kawasan ini. Taman nasional Komodo terletak di antara Kepulauan Sumbawa dan Flores, dekat dengan perbatasan antara Nusa tenggara timur dan nusa tengara barat. Taman nasional ini pertama kali dibangun pada tahun 1980 dan didesain sebagai Man and Biosphere Reserve oleh UNESCO pada tahun 1986. Taman nasional Komodo tetapkan sebagai situs warisan dunia oleh UNESCO pada tahun 1991.

Penataan yang dilakukan di kawasan taman mendapat perhatian lebih dari masyarakat dimulai dari adanya isu penataan pada Agustus 2018, di mana pada tahun tersebut tagar save Komodo pertama kali disuarakan masyarakat untuk menyatakan penolakan kepada pembangunan yang akan dilaksanakan di taman nasional Komodo yang akan dilakukan oleh PT. Segera Komodo Lestari. Dan pada masa itu muncul petisi online yang menyuarakan penolakan masyarakat atas adanya pembangunan di kawasan taman nasional Komodo. Pada tahun 2019, Gubernur NTT mewacanakan penataan kawasan taman nasional Komodo dengan tujuan konservasi dan wisata dan presiden Jokowi sudah menyepakati keputusan tersebut dan penataan akan dilakukan secara komprehensif.

Melihat perkembangan wacana dalam masyarakat, penataan di taman nasional Komodo dimaknai sebagai sesuai yang bersifat destruktif. Hal ini juga dapat dilihat dari munculnya respons negatif masyarakat ketika mengetahui adanya isu pembangunan di kawasan taman nasional Komodo, masyarakat berbondong menyuarakan ketidak setujuan mereka menggunakan tagar Save Komodo dan menandatangani petisi online. Selain itu, ketidak setujuan masyarakat juga dipengaruhi dengan status Komodo sebagai salah satu dari 
situs warisan dunia. Dalam perkembangannya Komodo dan keindahan alamnya yang alami selalu menjadi daya Tarik dari taman nasional ini. sehingga kemunculan bangunan asing akan mengganggu panorama alam yang ada dan dalam prosesnya akan pula mengganggu ekosistem yang ada pada kawasan ini.

Dari berkembangnya pemberitaan terkait dengan penataan taman nasional Komodo, tribunnews.com dalam melakukan konstruksi terkait dengan peristiwa ini cenderung berpihak kepada pemerintah dengan tujuan mengedukasi masyarakat bahwa penataan di taman nasional Komodo dilakukan dengan memperhatikan keselamatan Komodo dan menerapkan konsep pembangunan berkelanjutan. Sedangkan detik.com mengonstruksi peristiwa ini dengan mengkritisi penataan yang ada sehingga meningkatkan kesadaran masyarakat akan dampak-dampak buruk yang akan terjadi dari adanya penataan di kawasan taman nasional Komodo. Detik.com dalam hal ini merefleksikan pandangan masyarakat umum terkait dengan kekhawatiran akibat dampak yang akan muncul dari adanya penataan.

\section{Pembahasan \\ Konstruksi Peristiwa Penataan Taman Nasional Komodo pada Tribunews.com dan Detik.com}

Menurut analisis wacana kritis, penggunaan aspek kebahasaan yang diproduksi suatu media memiliki maksud dan tujuan tertentu (Eriyanto, 2017). Dari analisis yang dilakukan tribunnews.com dalam mengonstruksi peristiwa terkait dengan penataan taman nasional Komodo memiliki maksud untuk mengedukasi dan meyakinkan masyarakat bahwa penataan di taman nasional Komodo dilakukan dengan memperhatikan keselamatan Komodo dan menerapkan konsep pembangunan berkelanjutan. Sehingga masyarakat diharapkan tidak mengkhawatirkan dampak buruk dari penataan. Wacana pada media ini juga memiliki tujuan mengklarifikasi kontroversi yang muncul akibat viralnya foto Komodo yang berhadapan dengan sebuah truk di kawasan taman nasional Komodo. Sedangkan detik.com melalui wacana yang diproduksi bertujuan untuk meningkatkan kesadaran masyarakat akan dampak-dampak buruk yang akan terjadi dari adanya penataan di kawasan taman nasional Komodo dan berusaha mengkritisi penataan yang ada.

Hasil dari analisis teks yang menggambarkan keberpihakan media juga dipengaruhi oleh ideologi yang dianut media. Setiawan (2011) dalam penelitiannya menyatakan bahwa dari teks berita yang muncul pada suatu media menunjukkan ideologi dari media tersebut. Hal ini dapat dibuktikan dengan hasil analisis kognisi sosial yang telah dilakukan, tribunnews.com yang berorientasi profit berusaha untuk menampilkan berita secara cepat dengan judul clickbait yang digunakan untuk menarik perhatian masyarakat tanpa mementingkan isi konten yang dalam hal ini hanya menggunakan pernyataan yang disampaikan oleh pemerintah saja. Hal ini menjadikan wartawan pada media akan fokus juga pada profit dari hasil berita yang dipublikasikan. Sedangkan detik.com yang menerapkan komunikasi Pancasila berbasis ideologi Pancasila dalam memproduksi teks berusaha bersikap adil, hal ini ditunjukkan dari berita yang muncul pada media ini, di mana memuat keterangan yang menjelaskan kondisi terkini serta dampak negatif dari pembangunan yang ada di kawasan taman nasional. Sehingga waratawan pada media ini juga akan berusaha semaksimal mungkin untuk mencari kebenaran dan fakta dibalik suatu peristiwa. Hal ini sejalan didukung dengan hasil penelitian yang dilakukan oleh Setiawan (2011) juga menyatakan hal serupa, dimana media dalam melakukan pemberitaan terbukti memiliki bias yang diakibatkan oleh ideologi yang tersebar dan tertanam dalam tempat kerja wartawan.

Selain itu, apabila hasil dari analisis teks dihubungkan dengan analisis sosial, masyarakat memaknai penataan di taman nasional Komodo dimaknai sebagai sesuai yang bersifat destruktif. Hal ini juga dapat dilihat dari munculnya respons negatif masyarakat ketika 
mengetahui adanya isu pembangunan di kawasan taman nasional Komodo, masyarakat berbondong menyuarakan ketidak setujuan mereka menggunakan tagar Save Komodo dan menandatangani petisi online. Selain itu, ketidak setujuan masyarakat juga dipengaruhi dengan status Komodo sebagai salah satu dari situs warisan dunia. Selama berkembangnya wacana mengenai taman nasional Komodo, kebanyakan wacana diproduksi membahas mengenai satwa Komodo dengan segala keunikannya. Hal ini menjadikan satwa Komodo dimaknai sebagai satwa yang istimewa yang menjadi salah satu hal yang menjadi keistimewaan dari bangsa ini. Akan tetapi, pemaknaan ini tidak muncul dalam konstruksi peristiwa penataan taman nasional Komodo yang dilakukan oleh tribunnews.com di mana dalam teks berita yang muncul pada media ini, melihat sisi positif dan menyajikan banyak pernyataan pemerintah terkait dengan dampak baik serta tujuan dari penataan. Di lain sisi, detik.com menampikan kekhawatiran serta pemaknaan yang sama pula dengan bagaimana peristiwa dimaknai oleh masyarakat.

Dalam metode analisis wacana kritis dijelaskan bahwa ketiga elemen analisis merupakan hal yang berkesinambungan satu sama lain (Eriyanto, 2017). Hasil dari ketiga elemen analisis yang telah dilakukan menunjukkan kesinambungan antara satu elemen dengan elemen lainnya yang menunjukkan bahwa dalam mengonstruksi peristiwa terkait dengan penataan taman nasional Komodo masing-masing media menunjukkan keberpihakannya kepada satu pihak. Di mana tribunnews.com dalam memproduksi berita terkait dengan penataan di taman nasional Komodo berpihak kepada pemerintah dan Detik.com dalam memproduksi berita terkait dengan peristiwa ini berpihak kepada masyarakat yang menyuarakan penolakan.

\section{Keberpihakan Tribunnews.com dan Detik.com dalam Mengonstruksi Peristiwa Penataan Taman Nasional Komodo}

Dari analisis wacana kritis model van Dijk yang penulis lakukan kepada masing-masing 5 berita dari Tribunnews.com dan Detik.com, menunjukkan hasil bahwa masing-masing media menunjukkan keberpihakannya kepada satu pihak. Alfaritsi, et al, (2020) dalam penelitiannya juga menyatakan hal yang sama, dimana media akan cenderung memberikan dukungannya terhadap satu pihak. Tribunnews.com berpihak kepada pemerintah, mendukung adanya penataan dan detik.com berpihak kepada masyarakat yang menolak adanya penataan di taman nasional Komodo..

Melalui analisis kognisi sosial, ideologi media terbukti mempengaruhi bagaimana wacana diproduksi suatu media. Seperti yang dinyatakan Edy Prihantoro (2013) dalam penelitiannya bahwa wacana yang ada pada suatu media terbentuk sesuai dengan idealisme masing-masing media. Dalam hal ini tribunnews.com yang berorientasi profit berusaha untuk menampilkan berita secara cepat dengan judul clickbait yang digunakan untuk menarik perhatian masyarakat tanpa mementingkan isi konten yang dalam hal ini hanya menggunakan pernyataan yang disampaikan oleh pemerintah saja. Sedangkan detik.com yang menerapkan komunikasi Pancasila berbasis ideologi Pancasila dalam memproduksi teks berusaha bersikap adil, hal ini ditunjukkan dari berita yang muncul pada media ini, di mana memuat keterangan yang menjelaskan kondisi terkini serta dampak negatif dari pembangunan yang ada di kawasan taman nasional.

Hasil dari analisis ini menunjukkan bahwa media tribunnews.com dalam memproduksi berita terkait dengan penataan di taman nasional Komodo berpihak kepada pemerintah. Hal ini dapat dilihat dari bagaimana wartawan menampilkan berita dengan keterangan dari pemerintah dan tidak menampilkan keadaan dari penduduk setempat. Di sisi lain, Detik.com dalam memproduksi berita terkait dengan peristiwa ini berpihak kepada masyarakat yang menyuarakan penolakan, hal ini dapat dilihat dari bagaimana penulis memuat elemen teks yang memberikan penekanan kepada bagaimana pembangunan yang ada akan berdampak buruk baik dari segi ekonomi ataupun lingkungan.

Selain itu melalui analisis sosial dapat dilihat bagaimana berkembangnya isu ini menjadikan masyarakat semakin sadar akan pentingnya untuk menjaga alam hal ini dikarenakan dampak buruk yang muncul dari adanya pembangunan di taman nasional Komodo yang dikhawatirkan akan berujung kepada punahnya satwa ini. sehingga dalam hal ini, tribunnews.com dalam fungsinya sebagai media massa menjadi 
infrastruktur kekuasaan pemerintah untuk mengedukasi masyarakat bahwa penataan di taman nasional Komodo dilakukan dengan memperhatikan keselamatan Komodo dan menerapkan konsep pembangunan berkelanjutan. Sedangkan detik.com menjalankan fungsi media massa sebagai alat kontrol sosial yang berusaha mengkritisi penataan yang ada sehingga meningkatkan kesadaran masyarakat akan dampakdampak buruk yang akan terjadi dari adanya penataan di kawasan taman nasional Komodo.

\section{SIMPULAN}

Hasil dari ketiga elemen analisis masing-masing elemen mendukung hasil analisis satu sama lain. Tribunnews.com dalam melakukan konstruksi peristiwa penataan taman nasional Komodo terbukti menunjukkan keberpihakan politik kepada satu pihak yaitu pihak pemerintah dengan memberikan pandangan positif atas penataan yang ada. Sedangkan detik.com dalam mengonstruksi peristiwa penataan taman nasional Komodo terbukti menunjukkan keberpihakannya pada masyarakat yang menyuarakan penolakan atas adanya penataan di kawasan taman nasional Komodo. Hal ini dapat dilihat dari bagaimana berita yang diproduksi menampilkan sudut pandang dari penduduk setempat.

\section{DAFTAR PUSTAKA}

Al Kafi, M. S. (2020). Politik kekuasaan dalam pemberitaan media online analisis framing pemberitaan revisi undangundang komisi pemberantasan korupsi di detik.com

Alfaritsi, S., Anggraeni, D., \& Fadhil, A. (2020). Analisis wacana kritis berita 'tentang social distance', cara pemerintah cegah penyebaran virus corona di Detik.com. Jurnal Communicology, 8(1), 131-152

Ardhyanto, A., \& Ardiani, N. A. (2017). Tourism Impacts of Sail Komodo to the Development of Komodo District, Indonesia. Proceedings of the 6th
International Conference of Arte-Polis, 187-195

Arsam. (2014). Olygopoli, Kepemilikan Media dan Kebijakan Negara. Jurnal Komunikasi Penyiaran Islam, 149-168

Asriyani, H., \& Verheijen, B. (2020). Protecting the Mbau Komodo in Riung, Flores: Local Adat, National Conservation and Ecotourism Developments. Forest and Society, 4(1), 20-34

Bogia, Edward D. (2016). Diskursus Communism Phobia Dalam Teks Berita Borchers, H. (2005). Komodo Park; A future Jurassic tragedy. Diakses pada 26 November https://www.slideshare.net/h.borchers/j urassic-tragedy-presentation

Eriyanto. (2017). Analisis Wacana Pengantar Analisis Teks Media. Yogyakarta: LKIS Group

Humaira, H. W. (2018). Analisis Wacana Kritis (Awk) Model Teun A. Van Dijk Pada Pemberitaan Surat Kabar Republika. Jurnal Literasi, 2(1). 32-40

Hukumonline.com. (2020). Bolehkah Konsep Geopark Dibangun di Taman Nasional Komodo?, Diakses pada 7 November 2020.

https://www.hukumonline.com/klinik/d etail/ulasan/lt5f995fe432260/bolehkahkonsep-igeopark-i-dibangun-di-tamannasional-komodo/

Kurniawan, K. K. (2019). Understanding visitors' experiences in nature-based tourism: A case study of Komodo National Park Indonesia

Kusuma Wardani, C. N. L. (2017). Ideologi media tribunnews.com dan tempo.co dalam pemberitaan dua tahun kinerja pemerintahan jokowi-jk (analisis wacana kritis)

Keputusan Menteri Kehutanan Nomor 306/Kpts-II/1992 tanggal 29 Februari 1992

Lasso, A., \& Dahles, H. (2018). Are tourism livelihoods sustainable? Tourism development and economic 
transformation on Komodo Island, Indonesia transformation on Komodo Island, Indonesia. 1665. https://doi.org/10.1080/10941665.2018 .1467939

Mongabay.com. (2019). Demi Konservasi dan Wisata, Jokowi Minta Taman Nasional Komodo Ditata, Akankah Terlaksana?. Diakses pada 7 November 2020. https://www.mongabay.co.id/2019/07/ 14/demi-konservasi-dan-wisatajokowi-minta-taman-nasional-komododitata-akankah-terlaksana/

Nttprogresif.com. (2020). 13 Hal yang Perlu Anda Ketahui tentang Implementasi Pariwisata Super Premium dan Akibatnya bagi Kehidupan dan Penghidupan di dalam Taman Nasional Komodo. Diakses pada 26 November Santoso, P. (2016). Konstruksi Sosial Media Massa. Al-Balagh, 1(1), 30-48

Setiawan, Y. B. (2011). Analisis Wacana Kritis Pemberitaan Kekerasan Berbasis Gender Di Surat Kabar Harian Suara Merdeka. Jurnal Ilmiah Komunikasi, 2(1), 13-20

Sitorus, T. (2011). Linking Conservation of Biodiversity and Community Livelihood in Komodo National Park, Indonesia. Island Futures: Conservation and Development Across the AsiaPacific Region. 99-105. https://doi.org/10.1007/978-4-43153989-6_8

Sobur, A. (2018). Analisis Teks Media Suatu Pengantar Untuk Analisis Wacana, Analisis Semiotik, dan Analisis Framing. Bandung: PT Remaja Rosdakarya
2020.

https://nttprogresif.com/2020/07/27/13hal-yang-perlu-anda-ketahui-tentangimplementasi-pariwisata-superpremium-dan-akibatnya-bagikehidupan-dan-penghidupan-di-dalamtaman-nasional-komodo/

Prihantoro, E. (2013). Analisis wacana pemberitaan selebriti pada media. Proceeding PESAT (Psikologi, Ekonomi, Sastra, Arsitektur \& Teknik Sipil), 5, 8-9

Peraturan Pemerintah Republik Indonesia Nomor 28 Tahun 2011 tentang Pengelolaan Kawasan Suaka Alam dan Kawasan Pelestarian Alam

Peraturan Menteri Kehutanan Republik Indonesia Nomor P.4/Menhut-II/2012

Sugiyono, (2017). Metode Penelitian Kuantitatif, Kualitatif, dan R\&D. Bandung: ALFABETA

Similarweb.com. (2020). Detik.com vs Tribunnews.com. Diakses pada 7 November 2020. https://www.similarweb.com/website/d etik.com/?competitors=tribunnews.com

Tempo.co. (2018). Tiga Pemilik Media Massa di Barisan Pendukung Jokowi. Diakses $\begin{array}{llll}\text { pada } & 8 & \text { Februari } 2021 .\end{array}$ https://nasional.tempo.co/read/1125147 /tiga-pemilik-media-massa-di-barisanpendukung-jokowi?page num $=3$

Tribunnews.com. (2020). Tribunnews.com. Diakses pada 6 November 2020. https://www.tribunnews.com/about

Unesco.org. Komodo National Park. Diakses pada 7 November 2020. https://whc.unesco.org/en/list/609/ 